http://dx.doi.org/10.18778/1509-877X.02.02

Artykuły

Jan Paweł Tarno*

\title{
SUMA PIENIĘŻ̇A JAKO ŚRODEK DYSCYPLINUJĄCY W POSTĘPOWANIU SĄDOWO-ADMINISTRACYJNYM
}

\begin{abstract}
Streszczenie. Kontrola jest niezbędnym elementem każdego procesu administrowania. Sądowa kontrola administracji jest w obowiązującym systemie prawa podstawowym instrumentem zagwarantowania legalności działania organów administracji. Dlatego też kluczową rolę należy przypisać wykonalności orzeczeń sądów administracyjnych. Z tego też powodu sądy te zostały wyposażone w możliwość stosowania środków dyscyplinującego oddziaływania. Współcześnie obok typowych środków o charakterze represyjnym ustawodawca wprowadza instrumenty o charakterze prewencyjnym. Katalog środków dyscyplinujących ulega ciągłemu rozszerzeniu. Nowym rozwiązaniem prawnym jest ustanowiony w 2015 r. dodatkowy środek o charakterze dyscyplinująco-represyjnym, polegający na przyznaniu sumy pieniężnej od organu na rzecz skarżącego.
\end{abstract}

Słowa kluczowe: sądowa kontrola administracji, środki dyscyplinujące w postępowaniu sądowo-administracyjnym, grzywna, sygnalizacja, przyznanie sumy pieniężnej

1. Wykonywanie wyroków sądu administracyjnego, uwzględniających skargę polega na zastosowaniu się przez organ administracyjny w toku ponownego rozpoznania sprawy do oceny prawnej, wyrażonej w tym wyroku. Wynika to wprost $\mathrm{z}$ art. 153 p.p.s.a. ${ }^{1}$, zgodnie $\mathrm{z}$ którym ocena prawna i wskazania co do dalszego postępowania wyrażone w orzeczeniu sądu

* Profesor nauk prawnych, kierownik Zakładu Sądownictwa Administracyjnego na Wydziale Prawa i Administracji Uniwersytetu Łódzkiego, sędzia Naczelnego Sądu Administracyjnego.

${ }^{1}$ Ustawa z 30 sierpnia 2002 r. - Prawo o postępowaniu przed sądami administracyjnymi (Dz.U. z 2012 r., poz. 270 ze zm.). 
wiążą w sprawie organy, których działanie, bezczynność lub przewlekłe prowadzenie postępowania było przedmiotem zaskarżenia, a także sądy, chyba że przepisy prawa uległy zmianie. Ocena prawna wyrażona w orzeczeniu sądu wiąże w sprawie ten sąd oraz organ, którego działanie lub bezczynność była przedmiotem zaskarżenia. Oznacza to, że orzeczenie sądu administracyjnego wywiera skutki wykraczające poza zakres postępowania sądowoadministracyjnego, a jego oddziaływaniem objęte jest także przyszłe postępowanie administracyjne $\mathrm{w}$ danej sprawie. Ocena prawna wynika z uzasadnienia wyroku sądu i dotyczy wykładni przepisów prawnych i sposobu ich zastosowania w konkretnym przypadku w związku z rozpoznawaną sprawą. Zaś związanie samego sądu administracyjnego, w rozumieniu tego przepisu, oznacza, iż nie może on formułować nowych ocen prawnych - sprzecznych z wyrażonym wcześniej poglądem, lecz zobowiązany jest do podporządkowania się mu w pełnym zakresie oraz konsekwentnego reagowania $\mathrm{w}$ razie stwierdzenia braku zastosowania się przez organ do wskazań w zakresie dalszego postępowania przed organem administracji publicznej.

Biorąc pod uwagę fakt, że ocena prawna, o której tu mowa, jest wiążąca tylko o tyle, o ile odnosi się do tych samych okoliczności faktycznych i prawnych, to konsekwentnie należy przyjąć, że traci ona moc wiążącą jedynie w przypadku: 1) zmiany ustawy, 2) zmiany (już po wydaniu orzeczenia sądowego) istotnych okoliczności faktycznych sprawy, 3) wzruszenia tego orzeczenia w przewidzianym do tego trybie, a także 4) późniejszego podjęcia przez skład poszerzony NSA uchwały zawierającej ocenę prawną odmienną od wyrażonej we wcześniejszym wyroku sądu administracyjnego ${ }^{2}$.

Naruszenie przez organy administracyjne postanowień omawianego przepisu powoduje konieczność - w razie złożenia na tej podstawie skargi - uchylenia zaskarżonej decyzji (bądź innego aktu czy czynności). Stanowi to gwarancję przestrzegania przez organy administracji publicznej związania orzeczeniem sądu. Musi być konsekwentnie eliminowane przez uchylanie wadliwych z tego powodu rozstrzygnięć administracyjnych już chociażby z uwagi na związanie wcześniej przedstawioną oceną prawną także i samego sądu. Bez ścisłego stosowania omawianego przepisu trudno byłoby zresztą zapewnić spójność działania systemu władzy państwowej. Jego nieprzestrzeganie $\mathrm{w}$ istocie podważałoby bowiem obowiązującą w polskim prawie

${ }^{2}$ Por. uchwała składu 7 sędziów NSA z 30 czerwca 2008 r., I FPS 1/08, ONSAiWSA 2008, nr 5, poz. 75. 
zasadę sądowej kontroli nad aktami i czynnościami organów administracji - por. wyrok NSA z 21 października 1999 r., IV SA 1681/97. Natomiast niezastosowanie się do oceny prawnej wyrażonej w orzeczeniu sądu administracyjnego przez sąd jest naruszeniem prawa materialnego stanowiącym podstawę do wniesienia skargi kasacyjnej (art. 174 pkt 1 p.p.s.a.).

2. Powszechnie uważa się, że bezczynność organu lub przewlekłe prowadzenie postępowania jest jednym ze zbyt często spotykanych negatywnych zjawisk towarzyszących funkcjonowaniu administracji publicznej. Ponadto, zbyt często też się zdarza, że organy administracyjne, w tym organy podatkowe nie wykonują prawomocnych orzeczeń sądów administracyjnych. Sensem istnienia i działania administracji w państwie prawnym jest realizacja postawionych przed nią zadań publicznych. Przy tym jako jedną z zasad odnoszących się do działań organów administracji publicznej wyróżnia się zasadę efektywności, wskazując że pod nazwą tą kryje się sprawność, szybkość, skuteczność, czy też ekonomiczność działań podejmowanych przez organy administracji. W konsekwencji obywatel ma prawo oczekiwać od administracji działań, które będą miały takie właśnie cechy. Działania administracji powinny się więc charakteryzować tego rodzaju aktywnością, która jest skierowana na sprawne, terminowe i zgodne z prawem załatwienie konkretnej sprawy.

Nadto, obowiązek rozpatrzenia sprawy „w rozsądnym terminie” wynika $\mathrm{z}$ art. 6 Europejskiej konwencji o ochronie praw człowieka i podstawowych wolności (Dz.U. z 1993 r. Nr 61, poz. 284), a także z art. 17 Europejskiego Kodeksu dobrej administracji przyjętego przez Parlament Europejski w dniu 6.09.2001 r. Jednocześnie zaś „w wymiarze Unii Europejskiej zasada efektywności oznacza obowiązek ustanowienia odpowiednich reguł nadzoru nad działaniami podmiotów wewnątrzpaństwowych"3.

Scharakteryzowany wyżej sposób wykonywania orzeczeń sądów administracyjnych - co do zasady - sprawdza się w praktyce. Jednakże, jak wykazały doświadczenia z lat 2004-2015, zdarzają się coraz częściej przypadki niestosowania się przez organy administracji do oceny prawnej zawartej w prawomocnym orzeczeniu sądu administracyjnego, co jest równoznaczne $\mathrm{z}$ niewykonaniem takiego wyroku. Tym samym dowodzi to wniosku, że dotychczasowe środki dyscyplinowania organów administracji w tym względzie okazały się w tych przypadkach niewystarczające.

\footnotetext{
${ }^{3}$ J. Zimmermann, Prawo administracyjne, Kraków 2005, s. 109-110.
} 
Powyższa konstatacja dotyczy również efektywności sądowej kontroli w sprawach skarg na bezczynność organu lub przewlekłe prowadzenie postępowania. Wielokrotnie bowiem wyroki uwzględniające skargę w tym zakresie nie przynosiły oczekiwanych rezultatów. Tymczasem prawne, efektywne i terminowe działanie administracji jest przeciwieństwem bezczynności, która z kolei stanowi jeden z przejawów biurokracji. Bezczynność organu - rozumiana jako opieszałość, czy też zupełny brak oczekiwanych przez obywatela działań administracji - powszechnie jest uważana za jeden z przejawów biurokracji w ujęciu pejoratywnym, a więc za przejaw biurokratyzmu. Jest to zjawisko na wskroś niepożądane. Nic więc dziwnego, że zarówno w postępowaniach administracyjnych, jak i w postępowaniu sądowoadministracyjnym zostały uregulowane środki prawne mające na celu przeciwdziałanie temu zjawisku. Sprawne, efektywne i terminowe działanie administracji jest przeciwieństwem bezczynności, która z kolei stanowi jeden z przejawów biurokracji. Bezczynność organu - rozumiana jako opieszałość, czy też zupełny brak oczekiwanych przez obywatela działań administracji - powszechnie jest uważana za jeden z przejawów biurokracji w ujęciu pejoratywnym, a więc za przejaw biurokratyzmu. Jest to zjawisko na wskroś niepożądane. Nic więc dziwnego, że zarówno w postępowaniach administracyjnych, jak i w postępowaniu sądowoadministracyjnym zostały uregulowane środki prawne mające na celu przeciwdziałanie temu zjawisku. Jednym z rodzajów tych środków prawnych są instytucje procesowe określane mianem środków dyscyplinujących.

Niemniej jak wykazały to opisane powyżej doświadczenia - katalog tych środków okazał się niewystarczający. Dlatego też z dniem 15 sierpnia 2015 r. na skutek nowelizacji dokonanej ustawą z 9 kwietnia 2015 r. o zmianie ustawy - Prawo o postępowaniu przed sądami administracyjnymi ${ }^{4}$ wprowadzono nowy środek dyscyplinujący w postaci „przyznania sumy pieniężnej”. W uzasadnieniu do projektu tej noweli ${ }^{5}$ stwierdzono, że wprowadzając możliwość przyznania sumy pieniężnej, wzorowano się na rozwiązaniu przyjętym w ustawie z 17 czerwca 2004 r. o skardze na naruszenie prawa strony do rozpoznaniu sprawy w postępowaniu przygotowawczym prowadzonym lub nadzorowanym przez prokuratora i postępowaniu sądowym bez nieuzasadnionej zwłoki ${ }^{6}$. Podkreślić wszakże należy,

${ }^{4}$ Dz.U. z 2015 r., poz. 658.

${ }^{5}$ Druk sejmowy 1633, Sejm VII kadencji.

${ }^{6}$ Tekst jedn. Dz.U. z 2018 r., poz. 75, cyt. dalej jako „ustawa z 17 czerwca 2004 r.” 
że wspomniana ustawa była jedynie inspiracją do przyjęcia tego środka dyscyplinującego, a nie wzorcem do jego regulacji prawnej. Niewątpliwie stanowi on nową i odmienną kategorię prawną od przyjętej w ustawie z 17 czerwca 2004 r., ponieważ przyznanie sumy pieniężnej na gruncie obu tych ustaw pełni odmienne funkcje. Dlatego też zrozumiałe jest, że ta instytucja na gruncie postępowania sądowoadministracyjnego nie poddaje się jeszcze jednolitej ocenie, natomiast zdążyła wywołać pewne kontrowersje, zarówno w orzecznictwie sądowym, jak i w literaturze przedmiotu.

3. Pod pojęciem środków dyscyplinujących należy rozumieć środki prawne, których celem jest dyscyplinowanie działalności organów administracji publicznej, w szczególności na wypadek ich bezczynności ${ }^{7}$ lub niewykonywania prawomocnych wyroków sądów administracyjnych ${ }^{8}$. Aktualnie są one unormowane w art.: 55, 112, 145a, 154 i 155 p.p.s.a. i mają dość zróżnicowany charakter. Powszechnie wyróżnia się środki dyscyplinujące o charakterze: a) prewencyjnym (sygnalizacja), b) prewencyjno-represyjnym (grzywna) i c) prewencyjno-represyjno-kompensacyjnym ${ }^{9}$ (przyznanie stronie sumy pieniężnej). Niemniej, cechą wspólną ich wszystkich jest to, że działania podejmowane przez sądy administracyjne na powołanych wyżej podstawach mają zapewnić zwiększenie efektywności sądowej kontroli administracji publicznej.

Niniejsze opracowanie jest poświęcone jednemu z tych środków dyscyplinujących, jakim jest przyznanie sumy pieniężnej. Został on wprowadzony do Prawa o postępowaniu przed sądami administracyjnymi stosunkowo niedawno, bo od 15 sierpnia 2015 r. i z tego powodu linia orzecznicza sądów administracyjnych co do jego charakteru i zakresu stosowania nie jest jeszcze w pełni ukształtowana. Jest to tym bardziej zrozumiałe, że regulacja prawna tego środka prawnego jest więcej niż lakoniczna.

Instytucja „przyznania sumy pieniężnej” występuje w trzech przepisach p.p.s.a. Zgodnie $\mathrm{z}$ art. 145a $\$ 3 \mathrm{w}$ przypadku niewydania decyzji lub

${ }^{7}$ Por. szerzej M. Szewczyk [w:] J.P. Tarno, E. Frankiewicz, M. Sieniuć, M. Szewczyk, J. Wyporska, Sądowa kontrola administracji, podręcznik akademicki, Warszawa 2006, s. 293 i n.

${ }^{8}$ W. Sawczyn, Środki dyscyplinowania administracji publicznej w prawie o postępowaniu przed sadami administracyjnymi, Warszawa 2010, s. 25.

${ }_{9}$ Zdaniem M. Jagielskiej, J. Jagielskiego, M. Grzywacza i R. Stankiewicza jest to środek o charterze prewencyjno-represyjnym. M. Jagielska, J. Jagielski, M. Grzywacz, R. Stankiewicz, [w:] Prawo o postępowaniu przed sq̨dami administracyjnymi. Komentarz, red. R. Hauser, M. Wierzbowski, Warszawa 2017, s. 650. 
postanowienia w określonym przez sąd na podstawie art. $145 \mathrm{a} \$ 1$ p.p.s.a. terminie. Wówczas strona może wnieść skargę, żądając wydania orzeczenia stwierdzającego istnienie albo nieistnienie stosownego uprawnienia lub obowiązku. [...] Jednocześnie sąd w wyniku rozpoznania tej skargi obowiązany jest stwierdzić czy niewydanie decyzji lub postanowienia miało miejsce $\mathrm{z}$ rażącym naruszeniem prawa, a ponadto może $\mathrm{z}$ urzędu albo na wniosek strony wymierzyć organowi grzywnę w wysokości określonej $\mathrm{w}$ art. $154 \$ 6$ lub przyznać od organu na rzecz skarżącego sumę pieniężną do wysokości połowy kwoty określonej w art. $154 \$ 6^{10}$. Oznacza to, że sąd może jednocześnie zastosować oba te środki dyscyplinujące.

Z kolei stosownie do art. $149 \$ 2$ p.p.s.a., Sąd w przypadku uwzględnienia skargi na bezczynność lub przewlekłe prowadzenie postępowania może ponadto orzec $z$ urzędu albo na wniosek strony o wymierzeniu organowi grzywny w wysokości określonej w art. $154 \$ 6$ lub przyznać od organu na rzecz skarżącego sumę pieniężną do wysokości połowy kwoty określonej w art. $154 \S 6$.

Trzeci przypadek, w którym może dojść do przyznania sumy pieniężnej skarżącemu do wysokości połowy kwoty określonej w art. $154 \$ 6$ od organu administracji dotyczy sytuacji uwzględnienia przez sąd administracyjny skargi na niewykonanie wyroku uwzględniającego skargę na bezczynność organu lub przewlekłe prowadzenie postępowania (art. 154 p.p.s.a.).

4. Z przytoczonych przepisów płyną następujące konstatacje:

4.1. Warunkiem przyznania sumy pieniężnej w każdym $\mathrm{z}$ tych trzech przypadków jest uwzględnienie skargi. Podkreślenia wymaga, ze sąd może ją przyznać zarówno z urzędu, jak i na żądanie strony ${ }^{11}$. Oznacza to, że nawet gdyby skarżący nie wystąpił z wnioskiem o przyznanie mu sumy pieniężnej, to i tak sąd administracyjny mógłby orzec w tej kwestii z urzędu.

${ }^{10}$ W 2017 r. górna granica wysokości sumy pieniężnej, który sąd administracyjny mógł przyznać od organu wynosiła 17 684,35 zł.

${ }^{11}$ Wprawdzie art. $154 \$ 7$ p.p.s.a. nie stanowi o tym wprost, ale wykładnia systemowa całego art. 154 nakazuje przyjąć, że sąd może orzec w przedmiocie sumy pieniężnej zarówno z urzędu jak i na wniosek strony. Skoro przyznanie tej sumy następuje ponad to, co wynika z uwzględnienia skargi (wymierzenie grzywny), to sąd musi mieć możność zastosowania tego środka dyscyplinującego zarówno z urzędu, jak i na wniosek, jeżeli dojdzie do przekonania, że jest to niezbędne dla osiągnięcia celu skargi wnoszonej na podstawie art. $154 \$ 1$ p.p.s.a. 
Tym niemniej, mimo takiego rozwiązania przyjętego w ustawie, racjonalnym będzie z punktu widzenia skarżącego występowanie do sądu ze stosownym żądaniem, albowiem jeżeli strona chce przyznania takiej sumy, to wola skarżącego jest taką okolicznością stanu faktycznego sprawy, która nie powinna budzić jakichkolwiek wątpliwości sądu. Poza tym należy mieć na względzie, że brak wniosku o przyznanie sumy pieniężnej zwalnia sąd z obowiązku rozważenia tej kwestii.

4.2. Ustawodawca nie określił przesłanek, którymi powinien kierować się sąd przy przyznawaniu sumy pieniężnej, pozostawiając tę kwestię uznaniu sądu („sąd może przyznać”). Nie jest to jednak uznanie dowolne. Jest to wszakże uprawnienie orzecznicze sądu administracyjnego, który powinien z niego skorzystać stosownie do okoliczności faktycznych i prawnych konkretnej sprawy. Przykładowo, moim zdaniem nie ulega wątpliwości, że sąd administracyjny, który stwierdzi, że konkretne w danej sprawie uchybienie organu (odpowiednio: niewydanie decyzji lub postanowienia w określonym przez sąd terminie; bezczynność lub przewlekłe prowadzenie postępowania; niewykonanie wyroku uwzględniającego skargę na bezczynność organu lub przewlekłe prowadzenie postępowania) miało miejsce z rażącym naruszeniem prawa, może odstąpić od przyznania sumy pieniężnej skarżącemu tylko w szczególnie uzasadnionych wypadkach. Oznacza to w szczególności, że oddalając wniosek o przyznanie sumy pieniężnej, sąd będzie obowiązany wyjaśnić w uzasadnieniu podjętego orzeczenia, jakie to okoliczności uznał za szczególnie uzasadniony wypadek, uzasadniający odstąpienie od zastosowania tego środka dyscyplinującego (art. $141 \S 4$ p.p.s.a.).

4.3. Przyznanie sumy pieniężnej może nastąpić niezależnie od wymierzenia organowi grzywny. Oznacza to, że w stosunku do organu administracji mogą zostać zastosowane oba te środki dyscyplinujące o charakterze prewencyjno-represyjnym ${ }^{12}$, ponieważ przyznanie sumy pieniężnej pełni jeszcze jedną funkcję, a mianowicie funkcję kompensacyjną. Jest

${ }^{12} \mathrm{~W}$ orzecznictwie NSA prezentowany jest pogląd, że w przypadku wymierzenia grzywny sąd może również przyznać skarżącemu sumę pieniężną, jeżeli uzna, że dla realizacji zamierzonego celu, np. doprowadzenia do wykonania wyroku, nie wystarczy wymierzenie organowi grzywny - por. np. wyrok NSA z 11 kwietnia 2017 r., I OSK 1506/16. Pogląd ten nie budzi również wątpliwości w literaturze przedmiotu, por. np. M. Jagielska, J. Jagielski, M. Grzywacz, R. Stankiewicz, [w:] Prawo o postępowaniu przed sądami administracyjnymi. Komentarz, s. 626. 
ono zatem swoistym zadośćuczynieniem za krzywdę, jaką strona poniosła $\mathrm{z}$ powodu wadliwie działającej administracji publicznej. Przy tym sąd administracyjny nie bada, a nawet nie może badać, czy skarżący poniósł szkodę w wyniku nieprzestrzegania terminów przez organ. Ocenia jedynie wartość uciążliwości, z którymi musi borykać się skarżący w obronie swego interesu prawnego oraz skalę jego bezsilności, wywołanej świadomym odwlekaniem terminu załatwienia sprawy.

5. Warto dodać, że zaprezentowane stanowisko zostało zaakceptowane w orzecznictwie Naczelnego Sądu Administracyjnego. W wyroku z 11 maja 2018 r., I OSK 2230/16 NSA stwierdził m.in., że jedyną przesłanką warunkującą zarówno wymierzenie organowi grzywny, jak i przyznanie od organu na rzecz skarżącego sumy pieniężnej jest niewykonanie wyroku uwzględniającego skargę na bezczynność lub przewlekłe prowadzenie postępowania. Natomiast rozstrzyganie, który z tych środków, czy też oba $\mathrm{z}$ nich, ma zostać zastosowany i w jakiej wysokości zostało pozostawione orzecznictwu sądów administracyjnych. Nie ulega bowiem wątpliwości, że podejmując rozstrzygnięcie w kwestii zastosowania każdego z tych środków, sąd administracyjny powinien mieć na względzie: a) stopień naruszenia prawa przez organ administracyjny (funkcja represyjna), b) efektywność jego zastosowania, a więc wyrządzenie organowi określonej dolegliwości finansowej w celu przymuszenia go do wykonania prawomocnego wyroku (funkcja prewencyjna) i c) zasadność wynagrodzenia stronie cierpień i niedostatków związanych z niewykonaniem wyroku (funkcja kompensacyjna).

NSA podkreślił przy tym, że sąd administracyjny, który stwierdził w wyroku, że bezczynność organu lub przewlekłe prowadzenie postępowania przez organ miały miejsce $\mathrm{z}$ rażącym naruszeniem prawa, może odstąpić od wymierzenia grzywny i przyznania od organu na rzecz skarżącego sumy pieniężnej, jeżeli strona wystąpiła $\mathrm{z}$ takim wnioskiem, tylko w wyjątkowo uzasadnionych przypadkach. Oznacza to, że sąd administracyjny odstępując od przyznania skarżącemu sumy pieniężnej obowiązany jest wyjaśnić, jaki to wyjątkowo uzasadniony przypadek zaistniał, żeby uznać za uzasadnione odstąpienie od zastosowania tego środka dyscyplinującego. Stwierdził, że w rozpoznawanej sprawie, Sąd I instancji tego nie uczynił, ograniczając się do stwierdzenia, że nie widzi „obecnie potrzeby wymierzania organowi dodatkowej sankcji”, bo ta powinna być stosowana „W szczególnie drastycznych przypadkach zwłoki organu”. W rezultacie 
NSA uznał, że Sąd I instancji dokonał błędnej wykładni art. 154 \$ 7 p.p.s.a., powodując, że podniesiony w skardze kasacyjnej zarzut naruszenia tego przepisu ma usprawiedliwione podstawy.

Ponadto Naczelny Sąd Administracyjny zwrócił uwagę, że w kwestii wyboru właściwego środka dyscyplinującego sąd administracyjny powinien również pamiętać o zasadniczej różnicy, jaka występuje pomiędzy grzywną a sumą pieniężną. Wymierzenie grzywny organowi administracji, będącemu państwową jednostką budżetową, w gruncie rzeczy nie jest dolegliwością finansową (dotyczy to w szczególności organów podatkowych, które w znakomitej większości są państwowymi jednostkami budżetowymi - przyp. mój J. P. T.). W budżetach tych jednostek paragraf „kary” nie jest planowany. Zatem w przypadku wymierzenia organowi grzywny musi on wystąpić do dysponenta budżetu o przyznanie mu kwoty pieniężnej w wysokości wymierzonej grzywny. Po uzyskaniu tej kwoty, organ uiszcza grzywnę na konto właściwego sądu administracyjnego, który jest także państwową jednostką budżetową. Ta zaś z mocy prawa nie może mieć żadnych własnych dochodów. To powoduje, mówiąc w skrócie, że sąd musi te pieniądze „Zwrócić” budżetowi Państwa. Uznać zatem należy, że przedstawiony mechanizm, w określonych przypadkach istotnie obniża efektywność grzywny jako środka przymuszającego do wykonania prawomocnego wyroku sądu administracyjnego.

Tymczasem - zdaniem NSA - przyznanie skarżącemu sumy pieniężnej ma zawsze wymiar realnej dolegliwości finansowej. Ponadto, w procesie przyznawania od organu na rzecz skarżącego sumę pieniężnej należy mieć świadomość, czego aż nadto dowodzi niniejsza sprawa, że uzyskanie przez skarżącego korzystnego wyroku w sprawie ze skargi na bezczynność lub przewlekłe prowadzenie postępowania, nie oznacza jeszcze załatwienia sprawy administracyjnej. Wielokrotnie skarżący doznają usprawiedliwionego poczucia bezsilności. Zresztą Naczelnemu Sądowi Administracyjnemu $\mathrm{z}$ urzędu jest wiadome, że istnieje wiele spraw, w których wyroki sądów administracyjnych uwzględniające skargi na bezczynność lub przewlekłe prowadzenie postępowania nie są wykonywane, mimo wymierzania organom grzywien. Tak więc z punktu widzenia skarżącego wielokrotnie wymierzenie grzywny jest nieskutecznym środkiem przymusu. Przy tym dodać należy, że zjawisko to nie tylko godzi w interes prawny skarżących, ale także narusza powagę wymiaru sprawiedliwości, ponieważ u skarżącego musi narodzić się pytanie: „Co to za sąd, który nie potrafi wyegzekwować swoich wyroków?”. 
W rezultacie Naczelny Sąd Administracyjny stanął na stanowisku, że zastosowaniu tego środka dyscyplinującego przyświeca jeszcze jeden cel, który należy mieć na względzie przy interpretacji art. $154 \$ 7$ p.p.s.a. Przyznanie skarżącemu sumy pieniężnej ma także uświadomić skarżącemu, że nie jest on bezbronny $\mathrm{w}$ swoim sporze $\mathrm{z}$ organem administracji o zgodność z prawem zaskarżonego aktu lub czynności, bezczynności organu lub przewlekłego prowadzenia postępowania. Rozstrzygnięcie w przedmiocie sumy pieniężnej ma uświadomić skarżącemu, że sąd administracyjny widzi wszystkie dolegliwości i niedostatki, jakich on doznaje na skutek przewlekłego prowadzenia jego sprawy i że obejmuje skarżącego swoją ochroną. Mając to na uwadze, NSA stwierdził, że w rozpoznawanej sprawie przyznanie obu skarżącym sumy pieniężnej w wysokości po 10000 zł od Prezydenta m.st. Warszawy jest jak najbardziej zasadne, ponieważ bezczynność organu nie tylko miała miejsce $\mathrm{z}$ rażącym naruszeniem prawa, ale wręcz przyjęła postać kompletnego lekceważenia stron.

Jednocześnie Naczelny Sąd Administracyjny uznał, że Prezydentowi m.st. Warszawy została wymierzona grzywna przez sąd I instancji z naruszeniem art. $154 \$ 1$ i 6 p.p.s.a., ponieważ jest ona zbyt niska, aby przymusić ten organ do wykonania prawomocnego wyroku Wojewódzkiego Sądu Administracyjnego w Warszawie z 25 czerwca 2014 r., I SAB/Wa 145/14. Najlepszym tego dowodem jest fakt, że od daty wydania zaskarżonego wyroku WSA w Warszawie z 23 stycznia 2017 r., I SA/Wa 1738/16 upłynęło już ponad 15 miesięcy, a wyrok Wojewódzkiego Sądu Administracyjnego w Warszawie z 25 czerwca 2014 r. pozostaje w dalszym ciągu niewykonany.

Nawiasem mówiąc, omawiana sprawa, a właściwie okoliczności na nią się składające, jest najlepszym dowodem na to, jak nieskutecznym środkiem dyscyplinującym może się okazać wymierzenie organowi grzywny, zwłaszcza w niskiej wysokości.

6. Przyznać jednak należy, że omawiana instytucja spotkała się również z krytyką w literaturze przedmiotu ${ }^{13}$, choć moim zdaniem niezasłużoną. W szczególności zarzucono ustawodawcy, że:

${ }^{13}$ K. Świderski, „Suma pieniężna” w postępowaniu sądowoadministracyjnym, CASUS 2018, nr 88, s. 13 i n. 
6.1. Sąd administracyjny może przyznać na rzecz skarżącego sumę pieniężną również z urzędu ${ }^{14}$;

6.2. Nie wskazał dolnej granicy wysokości sumy pieniężnej, ani też żadnych kryteriów, którymi sąd administracyjny powinien się kierować przy ustalaniu wysokości sumy pieniężnej w konkretnej sprawie ${ }^{15}$;

6.3. W postępowaniu sądowoadministracyjnym sumę pieniężną przyznaje się od organu administracji publicznej, natomiast na gruncie ustawy z 17 czerwca 2004 r. sąd przyznaje na rzecz skarżącego sumę pieniężną od Skarbu Państwa ${ }^{16}$.

W rezultacie doszło do zdublowania się sankcji, które mogą być zastosowane $\mathrm{w}$ stosunku do organu prowadzącego postępowanie administracyjne (podatkowe). Zdaniem K. Świderskiego prowadzi to do całkiem zbytecznej sytuacji, która wymaga ustalenia przez sąd, która z tych sankcji jest bardziej dotkliwa i w jakim zakresie każda z nich może przyczynić się do spełnienia celu skargi na bezczynność organu lub przewlekłość postępowania lub niewykonanie wyroku ${ }^{17}$.

7. Nie można podzielić tych obaw i zastrzeżeń. Po pierwsze, różne są funkcje tych instytucji na gruncie ustawy z 17 czerwca 2004 r. i w postępowaniu sądowoadministracyjnym. W tym pierwszym przypadku jest to funkcja kompensacyjna i dlatego suma pieniężna jest przyznawana od Skarbu Państwa, ponieważ państwo ponosi odpowiedzialność za prawidłowe i zgodne z prawem funkcjonowanie swojego aparatu. Ponadto, realizacja tej funkcji wymaga określenia przesłanek, wedle których sąd będzie ustalał wysokość tej sumy.

Natomiast w postępowaniu sądowoadministracyjnym przyznanie skarżącemu sumy pieniężnej jest przede wszystkim środkiem dyscyplinującym, mającym w założeniu zmuszenie organu do działania zgodnego z prawem. To wyjaśnia, dlaczego sumę pieniężną przyznaje się od orga-

\footnotetext{
${ }^{14}$ Tamże, s. 14.

15 Tamże.
}

16 Tamże, s. 14-15, z wyjątkiem przypadku, kiedy przedmiotem postępowania jest przewlekłe prowadzenie postępowania przez komornika, wtedy sąd sumę pieniężną przyznaje od komornika.

${ }^{17}$ Tamże, s. 20. 
nu administracji publicznej, który nie dopełnił spoczywającego na nim obowiązku, a nie od Skarbu Państwa. Ten fakt uzasadnia również konieczność przyznania sądowi administracyjnemu możliwości zastosowania tego środka z urzędu. Wreszcie, skoro przyznanie sumy pieniężnej pełni jednocześnie funkcję prewencyjną, represyjną, a także kompensacyjną, to wystarczającą przesłanką zastosowania tej sankcji jest uwzględnienie skargi głównej (odpowiednio: niewydanie decyzji lub postanowienia w określonym przez sąd terminie; bezczynność lub przewlekłe prowadzenie postępowania; niewykonanie wyroku uwzględniającego skargę na bezczynność organu lub przewlekłe prowadzenie postępowania). Resztę trafnie pozostawiono uznaniu sądu administracyjnego, ponieważ on na gruncie konkretnej sprawy jest władny najtrafniej ocenić, względy jakiej natury powinny zadecydować zarówno o zastosowaniu tego środka dyscyplinującego, jak i o jego wysokości, aby wyegzekwować zamierzony cel.

8. Podsumowując, należy stwierdzić, że przyznanie sumy pieniężnej ma charakter środka represyjnego, a więc sankcji za ignorowanie przepisów o terminach załatwiania spraw administracyjnych, w tym podatkowych, a także za nierespektowanie prawomocnych wyroków. Zatem podwojenie sankcji o charakterze finansowym z dniem 15 sierpnia 2015 r. należy uznać nie tylko za celowe działanie ustawodawcy, ale i racjonalne. Po pierwsze, wymierzenie grzywny nie zawsze jest wystarczająco skutecznym środkiem dyscyplinującym organy do terminowego załatwiania spraw, przede wszystkim dlatego, że nie zawsze to jest dla organu zwłaszcza administracji rządowej realna dolegliwość finansowa, skoro Skarb Państwa nie doznaje uszczerbku. W gruncie rzeczy przecież dochodzi jedynie do przesunięć MW budżetach poszczególnych jednostek budżetowych. Po drugie zaś, zastosowanie środka dyscyplinującego w postaci przyznania sumy pieniężnej od organu zapewnia skarżącemu swoistego rodzaju zadośćuczynienie za wszelkiego rodzaju dolegliwości, których doznał w wyniku niewywiązania się organu ze spoczywających na nim obowiązków, zwłaszcza gdy miało to miejsce $\mathrm{z}$ rażącym naruszeniem prawa. Ma to szczególnie istotne znaczenie, jeżeli wziąć pod uwagę fakt, że strona w relacji z organem administracji publicznej zawsze zajmuje pozycję słabszą i to niezależnie od tego na gruncie jakiej sprawy powstał łączący ich stosunek administracyjnoprocesowy. 


\title{
BibLIOGRAFIA
}

Hauser R., Wierzbowski M. (red.), Prawo o postępowaniu przed sq̨dami administracyjnymi. Komentarz, Warszawa 2017.

Sawczyn W., Środki dyscyplinowania administracji publicznej w prawie o postępowaniu przed sąami administracyjnymi, Warszawa 2010.

Świderski K., „Suma pieniężna” w postępowaniu sadowoadministracyjnym, CASUS 2018, $\mathrm{nr} 88$.

Tarno J.P., Frankiewicz E., Sieniuć M., Szewczyk M., Wyporska J., Sądowa kontrola administracji, podręcznik akademicki, Warszawa 2006.

Zimmermann J., Prawo administracyjne, Kraków 2005.

\begin{abstract}
Judicial control is an immanent element of every administration process. Administrative courts are the basic guarantor of the legality of administrative bodies in the current legal system, to which, apart from the primary role of the administration of justice. Therefore, the feasibility sentences of administrative courts plays the main role in this process. For this reason, the legislator has given them to the function of disciplining influence. Today, apart from typical repressive measures, the legislator introduces preventive instruments. It should also be emphasized that the catalogue of disciplining measures is continuously expanding. A new legal solution is established in 2015 additional measure of a disciplinary and repressive nature, that is granting of a sum of money from the authority to the complainant.
\end{abstract}

Keywords: Judicial control over the administration, disciplining measures in the judicial proceedings, signaling, granting of a sum of money 